\section{Mortality from AIDS and tuberculosis-HIV coinfection in the Chilean AIDS Cohort of 2000-2017}

\author{
Mortalidad por SIDA y coinfección por \\ tuberculosis-VIH en la Cohorte Chilena de SIDA \\ de 2000-2017
}

\begin{abstract}
Mortalidade por aids e coinfecção tuberculose-HIV na Coorte Chilena de Aids de 2000-2017
\end{abstract}

Carlos Sanhueza-Sanzana 1
Ligia Kerr 1
Carl Kendall 1,2

doi: 10.1590/0102-311X00212920

\begin{abstract}
This article aims to assess the sociodemographic and epidemiological factors associated with AIDS and tuberculosis-HIV coinfection mortality in the Chilean adult population between 2000 and 2017. This is a retrospective observational study, evaluating the incidence density of TB-HIV coinfection mortality in the population over 14 years of age. We used data from the Chilean AIDS Cohort database, 17,512 people enrolled in highly active antiretroviral therapy in the public health system in Chile. The Kaplan-Meier survival function and Cox regression were applied. Incidence density of 0.05 for 39,283 person-years for mortality with TB-HIV coinfection was recorded, with an increase in new cases in people living with AIDS among Aymara and Mapuche indigenous populations. Risk factors included CD $4500 \mathrm{cells} / \mathrm{mm}^{3}$ $(H R=3.2 ; 95 \% C I: 2.2-4.9)$, viral load at the start of treatment $>10,000$ copies/uL (HR = 1.3; 95\%CI: 1.2-1.6). Having high school or higher education $(H R=0.76$; 95\%CI: 0.6-0.9) is a protective factor for mortality for coinfection. Mortality was concentrated in TB-HIV coinfected people with increasing mortality among women and indigenous populations. The paper contributes to the growing recognition of the role of social determinants in disease outcomes, and the requirement to improve community-focused and communitybased testing, sex education in schools, and structural interventions to reduce the adult mortality in Chilean population.
\end{abstract}

HIV; AIDS; Tuberculosis; Adult; Mortality

\author{
Correspondence \\ C. Sanhueza-Sanzana \\ Programa de Pós-graduação em Saúde Pública, \\ Departamento de Saúde Comunitária, Faculdade de Medicina, \\ Universidade Federal do Ceará. \\ Rua Prof. Costa Mendes 1608, Fortaleza, CE 60430-140, Brasil. \\ carlosanhueza.san@gmail.com \\ 1 Faculdade de Medicina, Universidade Federal do Ceará, \\ Fortaleza, Brasil. \\ 2 School of Public Health and Tropical Medicine, \\ Tulane University, New Orleans, U.S.A.
}




\section{Introduction}

It is estimated that 38 million people are currently living with HIV worldwide. An early report from the Joint United Nations Program on HIV/AIDS (UNAIDS) indicated that by 2017 a reduction in the annual number of deaths from AIDS-related illnesses would have been reached at all ages, from 1.9 million (1.4-2.7 million) in 2004 to $940,000(670,000-1,300,000)$ representing a 34\% reduction, attributable to the global expansion of antiretroviral treatment 1,2. In this scenario, far from the UNAIDS "accelerated response" objectives, Latin America maintained a stable trend in the incidence of new HIV-AIDS infections 3 .

However, since the peak of new HIV infections, there has been a $40 \%$ reduction, registering 1.7 (95\%CI: 1.4-2.3) million new HIV infections in 2018, compared to 2.9 (95\%CI: 1.4-2.3) million in 1997. Since 2010, these infections have been reduced by $16 \%$, whereas new infections in children have been reduced by $41 \%$, from 280,000 to 160,000 children in 2018 , which is attributed to the combined prevention strategies, besides the prevention protocols for vertical transmission 4 .

Chile, however, according to UNAIDS estimates, was the country in the region of the Americas where there was the greatest increase in new HIV infections, of $34 \% 2$, joining a group of 14 countries worldwide with the largest increase of new HIV infections in the adult population, of more than $50 \%$ between 2010 to 2017 , mainly of 25 to 29 year old, with a rate of 109.5 per 100,000 inhabitants 5,6. Another aspect is the increase of infections in women, with the male-female ratio of 5.3 in 2017, compared to 18.3 in the early $1990 \mathrm{~s} 6,7$.

Tuberculosis (TB)-HIV coinfection is a public health problem of global importance. In the Americas, the World Health Organization (WHO) estimated for 2017 that 36 million people lived with TB, causing approximately 1.3 million deaths among HIV negative persons and more than 300,000 deaths among HIV positive persons 8,9 .

People living with the HIV/AIDS (PLWHA) are a serious public health problem worldwide. In the last decades, the introduction of highly active antiretroviral therapy - HAART, ART here - has drastically changed the course of the HIV/AIDS epidemic, leading to a decrease in mortality rates due to AIDS-related deaths, thus increasing survival and substantially improving the quality of life of PLWHA. Cohort studies show that the life expectancy for people starting ART has increased by 10 years; however, it still remains below the general population 10,11,12,13.

Among HIV-related diseases, TB remains the leading cause of death in people with HIV-TB. On average, in the world, an HIV-infected person is 21 times more likely to develop active TB than an HIV-negative person 8 .

Although ethnicity emerges as a risk factor for mortality worldwide $14,15,16$, it is a phenomenon rarely explored in Chile, with some exceptions 17,18 . There is evidence that ethnicity affects clinical, socioeconomic and therapeutic conditions. For example, it is known that indigenous Mapuche enter treatment at a more advanced stage of disease, and consequently suffer higher morbidity and earlier mortality 17 .

Overall, mortality is lower in more egalitarian societies 19 . Thus, inequality can be considered as one of the main causes of death, and a special concern of study in societies as unequal as Latin American ones 20. Among the most important comorbidities in patients with HIV and associated with inequality, is infection by Mycobacterium tuberculosis 21,22. To assess the disparities on the health of the Chilean population living with HIV/AIDS, this study aimed to assess the sociodemographic and epidemiological factors associated with AIDS and TB-HIV coinfection mortality in the Chilean adult population between 2000 and 2017.

\section{Materials and methods}

This is a retrospective study that analyzes secondary sources of information provided by the Department of Epidemiological Surveillance of the Chilean Ministry of Health, using data from the Chilean AIDS Cohort, which contains information on 31,202 patient cases admitted to ART in the Chilean health system since 2000 . 
Information on treatment initiation, sex, age, clinical stage and opportunistic diseases, education, ethnicity, coinfections, comorbidities, final results (death or abandonment of treatment), intermediate results (CD4 counts, viral load - VL), adverse effects of ART drugs, and staging changes due to toxicity and failures, are contained in the dataset. The patients were treated in 39 special public health centers in the country. Sociodemographic data were collected at the initiation of ART.

The Chilean AIDS Cohort is part of a centralized program of the Ministry of Health to expand access to ART, that uses a prospective and multicenter evaluation model, measuring CD4+ cell counts and VL 13,23. Attribution of the cause of death due to AIDS is defined according to the 10th revision of the International Classification of Diseases (ICD-10), and the protocols of the Chilean Ministry of Health, stipulated in the Clinical Guide for Treatment of PLWHA 24. Opportunistic diseases and comorbidities existing at follow-up visits are added to the database.

Demographic statistics derived from the population projection developed by the 2017 Demographic Census of the Chilean National Statistics Institute (INE) were used to estimate the denominator for the HIV/AIDS prevalence rates for individuals aged 15 years and over tested for HIV.

The country's total population for 2021 is estimated at 19,678,363 inhabitants, distributed across 16 regions with an estimated area of $2,006,096 \mathrm{~km}^{2}$, a demographic density of 653 inhabitants per $\mathrm{km}^{2}$, of which $87.8 \%$ classified as urban. The indigenous population is comprised of 2,185.729 individuals 25,26 .

All individuals with a diagnosis of HIV/AIDS admitted to follow-up in the Chilean AIDS Cohort, aged 15 years and over, male and female, with treatment start date of January 1st, 2000 to December 31, 2017 were eligible for inclusion.

The technique of direct standardization for the prevalence of HIV/AIDS in the adult population of the Chilean AIDS Cohort was used to eliminate the influence of confounding factors, such as the structure of the age groups of each region and sex, considering the criteria of the chosen technique, population size for region (Equation 1).

$D i=$ the number of PLWHA in the age range $i(R i)$.

$P i=$ population in the mid-term of period in the $R i$, is then given by:

$$
R i=\frac{D i}{P i} \text { Expressed per 100,000 inhabitants }
$$

The HIV/AIDS prevalence rate was adjusted for age, being a weighted average of age-specific rates (Equation 2).

$P s i=$ The population in the $R i$ in the standard population. The standard weights are then given by:

$$
W_{s i}=\frac{P_{s i}}{\Sigma_{i} P_{s i}}
$$

In which $0<W i<1$. The age-adjusted HIV/AIDS prevalence rate (AAPR given by) (Equation 3) is:

$$
A A P R=\Sigma_{i} W_{S i} * \frac{D i}{P i}=\Sigma_{i} W_{S i} * R i
$$

\section{Statistical analyses}

Descriptive statistics for the sociodemographic and epidemiological profile of the population were developed. Hypothesis tests were applied to the categorical variables using Fisher's exact test and Pearson's chi-square test. Measures of central tendency (average, median and mod) and dispersion measures, standard deviation, and their respective confidence intervals for continuous measurements were estimated, once the normality of the distribution of the response variables was assessed using the Shapiro-Wilk test.

Global survival functions were estimated using the Kaplan-Meier curve method for the crude analysis of sociodemographic and epidemiological factors associated with the survival of patients coinfected with TB-HIV by the log-rank test, accepting a probability of error of less than 5\%, with their respective confidence intervals. Cox's semi-parametric model of proportional hazards ratios (HR) was applied 27,28,29. Besides, the proportionality assumption of the errors were tested for the 
diagnosis of the Cox model and the subsequent evaluation of the proportionality of its residues, using the Schoenfeld test. The organization, cleaning and analysis of the data were performed in Stata, version 16 (https://www.stata.com).

The adjusted prevalence rates of PLWHA, and people that indicated ART and entered the Chilean AIDS Cohort were estimated using intervals with similar time gaps for the years 2000-2005, 20062011 and 2012-2017 to know and describe how the prevalence rates were distributed in the country, and to compare them between regions following the reports and current estimates on HIV and AIDS infections conducted by the Chilean Ministry of Health in the Nacional Prevention and Control Plan of HIV/AIDS and its reports ${ }^{30}$. Descriptive maps of spatial distribution of HIV/AIDS prevalence rates were constructed in QGIS, version 3.12.1 (https://qgis.org/en/site/).

\section{Ethical aspects}

The data used corresponds to data that use publicly available information under the Law n. 12,527 (November 18, 2011), provided for in Resolution n. 510 (April 7, 2016). We declare that the project was adhered to the regulatory frameworks of Chile, as established in Law n. 20,285 ("Transparency and access to public information"), and in Law n. 19,628 ("Protection of private life").

\section{Results}

The highest HIV/AIDS prevalence rates were registered in the northern regions of the country, Arica y Parinacota, with a rate of 7.5 per 100,000 inhabitants, followed by Valparaiso region, with 5.0 per 100,000 inhabitants in the center and in the metropolitan region of Santiago with 4.2 per 100,000 inhabitants. These rates were greater than those estimated for the whole country, 3.0 per 100,000 inhabitants, and showed a significant increase between each observation period (Figure 1). We emphasize the region of Arica y Parinacota and Tarapaca, where prevalence increased 3.3 times from the first observation period (Figure 1).

The distribution of cases of PLWHA enrolled in ART increased in the second period. It was higher in the cities of the north of the country in the Arica y Parinacota region, with a prevalence between 16.6 and 21.5 per 100,000 inhabitants, followed by the regions of Copiapo, Araucanía and Los Lagos with prevalence between 9.7 and 13.6 per 100,000 inhabitants (Figure 1).

Regarding the specific prevalence rates by sex, the region that registered the highest rates per period correspond to the region of Arica y Parinacota (Figure 1), with this region having the highest prevalence, showing a temporal pattern of admitted cases.

We identified 17,512 individuals with both HIV and TB, of whom 87.6\% were men. Over time, women represented a larger portion of the sample. This reinforces the hypothesis of HIV feminization in Chile (Table 1).

The main route of transmission was the sexual, with injection drug use reported at low rates: 0.3 (2012-2017). Regarding age group, there is a significant increase among 15-29 years-old, which represented $42.7 \%$ of the population in the third period, compared to $34.2 \%$ in the period $2000-2005$. This increase was slightly smaller in the 30 to 49 years-old age group, being 1.4 times greater than the period from 2000-2005.

During the period analyzed, we found 2,013 death recorded, representing $11 \%$ of the total, with a higher proportion of deaths, $31.8 \%$, in the first period (2000-2005). These decreased to $5.2 \%$ in the last period, which is consistent with a higher probability of survival due to the effects of ART and improved care (Table 2).

Regarding CD4 lymphocytes, $72.5 \%$ of patients in 2000-2005 were enrolled with counts below 350 cells $/ \mathrm{mm}^{3}$. This patient percentage decreased in the last period to $66.1 \%$. However, when analyzing frank disease, there was a greater increase over time in people that entered in better health. For example, those in stage $\mathrm{A}$ in the first period were $43.9 \%$, rising to $45.6 \%$ in the second period, and finally, $69.3 \%$ in the final period.

We found an incidence density of 0.05 per 39,283 person-years for TB-HIV coinfection mortality in the Chilean AIDS Cohort. We estimate an average survival of 11 years after initiating ART, which 


\section{Figure 1}

Prevalence rates of people living with HIVIAIDS among adult population adjusted by population sizes by region. Chile, $2000-2017$.

1a) $2000-2005$

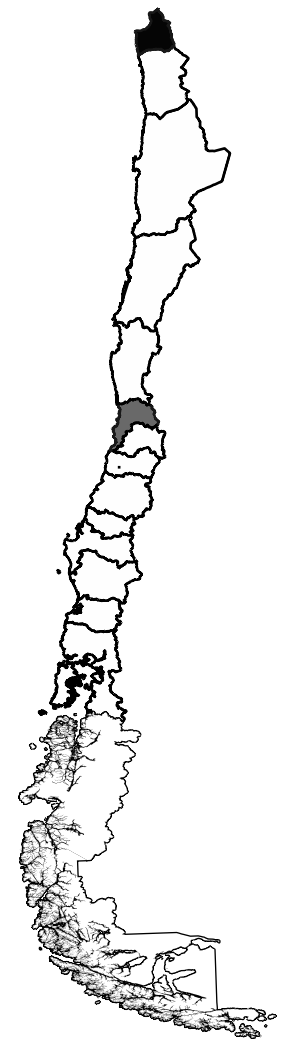

1b) $2006-2011$

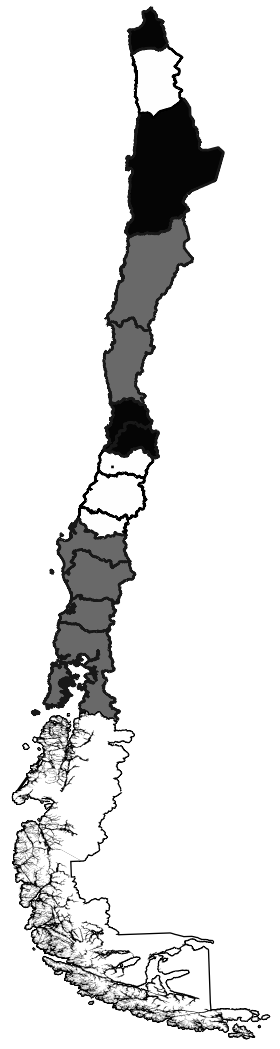

1c) $2012-2017$

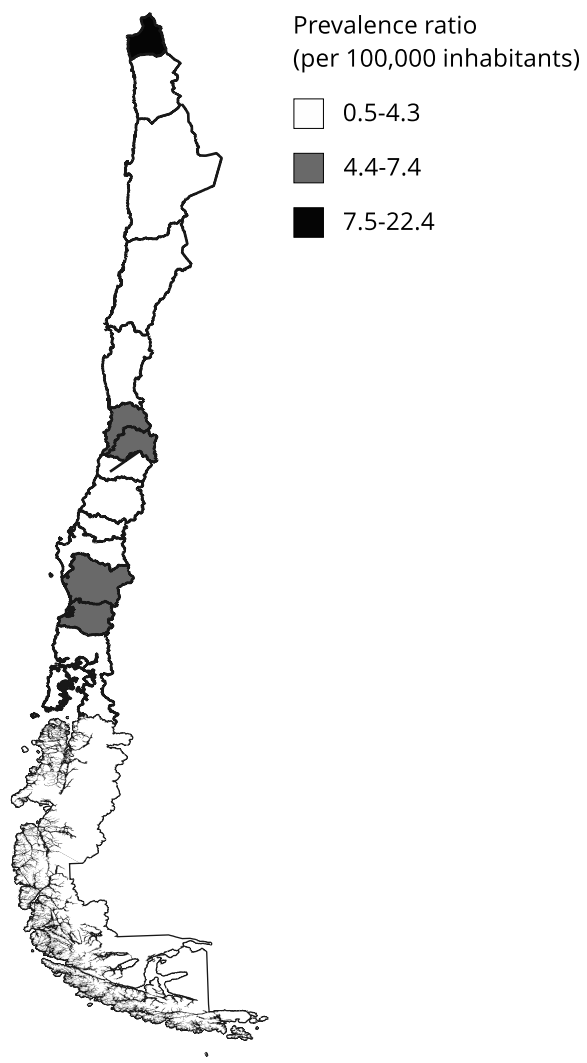

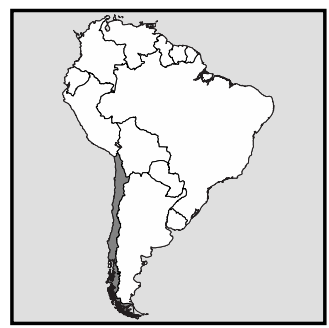

Source: Chilean AIDS Cohort analysis, 2000-2017, and Chilean National Institute of Statistics (INE). 
Table 1

Characterization of the sociodemographic profile of people living with HIV/AIDS, according to the initiation of highly active antiretroviral therapy. Chilean AIDS Cohort, 2000-2017 ( $N=17,512 *)$.

\begin{tabular}{|c|c|c|c|c|c|c|c|c|c|c|c|c|}
\hline \multirow[t]{3}{*}{ Variable } & \multicolumn{4}{|c|}{$2000-2005(n=2,811)$} & \multicolumn{4}{|c|}{$2006-2011(n=9,402)$} & \multicolumn{4}{|c|}{$2012-2017(n=5,299)$} \\
\hline & \multirow[t]{2}{*}{$\mathbf{n}$} & \multirow[t]{2}{*}{$\%$} & \multicolumn{2}{|c|}{$95 \% \mathrm{Cl}$} & \multirow[t]{2}{*}{$\mathbf{n}$} & \multirow[t]{2}{*}{$\%$} & \multicolumn{2}{|c|}{$95 \% \mathrm{Cl}$} & \multirow[t]{2}{*}{$\mathbf{n}$} & \multirow[t]{2}{*}{$\%$} & \multicolumn{2}{|c|}{$95 \% \mathrm{Cl}$} \\
\hline & & & Lower & Upper & & & Lower & Upper & & & Lower & Upper \\
\hline \multicolumn{13}{|l|}{ Sex } \\
\hline Man & 2,491 & 88.6 & 87.4 & 89.7 & 8,388 & 89.2 & 88.5 & 89.8 & 4,446 & 83.7 & 82.9 & $84.8 * *$ \\
\hline Woman & 319 & 11.4 & 10.2 & 12.5 & 1,014 & 10.7 & 10.1 & 11.4 & 848 & 16.2 & 15.1 & 17.0 \\
\hline \multicolumn{13}{|l|}{ Age group (years) } \\
\hline $15-29$ & 956 & 34.2 & 32.4 & 36.0 & 2,483 & 26.6 & 25.7 & 27.5 & 2,115 & 42.7 & 41.3 & $44.1 * *$ \\
\hline $30-49$ & 1,711 & 61.3 & 59.4 & 63.1 & 5,939 & 63.8 & 62.8 & 64.7 & 2,482 & 50.2 & 48.7 & 51.5 \\
\hline$\geq 50$ & 124 & 4.4 & 3.6 & 5.2 & 885 & 9.5 & 8.9 & 10.1 & 349 & 7.1 & 6.3 & 7.7 \\
\hline \multicolumn{13}{|l|}{ Migrant } \\
\hline Chilean & 2,734 & 98.4 & 97.9 & 98.9 & 9,136 & 97.6 & 97.3 & 97.9 & 4,738 & 90.1 & 89.3 & $90.9 * *$ \\
\hline Migrant & 45 & 1.6 & 1.1 & 2.0 & 226 & 2.4 & 2.1 & 2.7 & 518 & 9.9 & 9.0 & 10.6 \\
\hline \multicolumn{13}{|l|}{ Indigenous *** } \\
\hline No & 2,683 & 98.7 & 98.3 & 99.1 & 9,002 & 98.5 & 98.3 & 98.7 & 4,533 & 96.8 & 96.3 & $97.3 * \star$ \\
\hline Yes & 34 & 1.2 & 0.01 & 0.02 & 136 & 1.4 & 0.01 & 0.02 & 148 & 3.2 & 0.02 & 0.04 \\
\hline \multicolumn{13}{|l|}{ Education (years) } \\
\hline$<8$ & 277 & 15.5 & 13.7 & 17.1 & 646 & 14.1 & 13.1 & 15.1 & 594 & 12.5 & 11.6 & 13.5 ** \\
\hline $8-12$ & 968 & 54.0 & 51.7 & 56.3 & 2,361 & 51.6 & 50.2 & 53.1 & 2,116 & 44.7 & 43.3 & 46.1 \\
\hline Higher & 547 & 30.5 & 28.3 & 32.7 & 1,566 & 34.2 & 32.9 & 35.6 & 2,026 & 42.8 & 41.4 & 44.1 \\
\hline \multicolumn{13}{|l|}{ Occupation } \\
\hline Employed & 1,540 & 73.6 & 71.7 & 75.5 & 3,822 & 73.3 & 72.0 & 74.5 & 3,588 & 71.4 & 70.1 & 72.6 ** \\
\hline Unemployed & 474 & 22.7 & 20.8 & 24.4 & 1,093 & 20.9 & 19.8 & 22.0 & 716 & 14.3 & 12.2 & 15.5 \\
\hline Student & 51 & 2.4 & 1.7 & 3.0 & 252 & 4.8 & 4.2 & 5.4 & 669 & 13.3 & 12.3 & 14.2 \\
\hline Retired & 27 & 1.3 & 0.1 & 1.7 & 50 & 1.0 & 0.6 & 1.2 & 50 & 1.0 & 0.7 & 1.2 \\
\hline \multicolumn{13}{|l|}{ Transmission } \\
\hline Sexual & 955 & 78.7 & 76.6 & 80.9 & 2,452 & 71.4 & 69.8 & 72.9 & 3,597 & 82.0 & 80.9 & 83.2 ** \\
\hline IDU & 19 & 1.6 & 0.8 & 2.2 & 33 & 1.0 & 0.6 & 1.2 & 15 & 0.3 & 0.1 & 0.5 \\
\hline Another & 240 & 19.7 & 17.5 & 22.0 & 949 & 27.6 & 26.1 & 29.1 & 770 & 17.5 & 16.4 & 18.6 \\
\hline
\end{tabular}

95\% Cl: 95\% confidence interval; IDU: injection drug use.

Source: Chilean AIDS Cohort, 2000-2017.

* The differences in the "total $n$ " are due to "missing values";

** It represents total proportions and significant differences for Fisher's exact test with a probability of error < 0.001 ;

*** Aymara indigenous people represent 32\% and Mapuche indigenous people represent $60.3 \%$ of indigenous population.

means that people initiating ART in the country's public health system have a 53\% probability of survival of 6 to 8 years. We found that men have a lower survival rate when compared with women $(\mathrm{p}<0.001)$ (Figure 2).

With respect age groups, people over 40 years of age survived slightly less than the group between 30 to 39 and 15 to 29 years of age, with statistically significant differences. A lower survival was observed in people with elementary education or less compared those with middle school or higher. These differences are statistically significant $(\mathrm{p}<0.001)$ (Figure 2$)$.

We adjusted a multivariate model for people coinfected with TB-HIV, to evaluate the factors of risk associated with mortality in PLWHA (Equations 4-5). Our findings show that individuals enrolled in ART with TB have a much higher risk of dying ( $\mathrm{HR}=1.9 ; 95 \% \mathrm{CI}$ : 1.2-1.7) (Figure 2). Besides, people coinfected with TB-HIV that entered with a CD4 count below 500 cells $/ \mathrm{mm}^{3}(\mathrm{HR}=3.3$; $95 \% \mathrm{CI}$ : 2.2-4.9) (Figure 2), AIDS stage ( $\mathrm{HR}=1.9 ; 95 \% \mathrm{CI}$ : 0.9-3.8), and viral load above 10,000 copies/uL 
Table 2

Epidemiological profile of people living with HIV/AIDS by initiation of highly active antiretroviral therapy. Chilean AIDS cohort, 2000-2017 ( $\mathrm{N}=17,512 *$ ).

\begin{tabular}{|c|c|c|c|c|c|c|c|c|c|c|c|c|}
\hline \multirow[t]{3}{*}{ Variable } & \multicolumn{4}{|c|}{$2000-2005(n=2,811)$} & \multicolumn{4}{|c|}{$2006-2011(n=9,402)$} & \multicolumn{4}{|c|}{$2012-2017(n=5,299)$} \\
\hline & \multirow[t]{2}{*}{$\mathbf{n}$} & \multirow[t]{2}{*}{$\%$} & \multicolumn{2}{|c|}{$95 \% \mathrm{Cl}$} & \multirow[t]{2}{*}{$\mathbf{n}$} & \multirow[t]{2}{*}{$\%$} & \multicolumn{2}{|c|}{$95 \% \mathrm{Cl}$} & \multirow[t]{2}{*}{$\mathbf{n}$} & \multirow[t]{2}{*}{$\%$} & \multicolumn{2}{|c|}{$95 \% \mathrm{Cl}$} \\
\hline & & & Lower & Upper & & & Lower & Upper & & & Lower & Upper \\
\hline \multicolumn{13}{|l|}{ Deaths } \\
\hline Yes & 894 & 31.8 & 30.8 & 33.5 & 844 & 9.0 & 8.3 & 9.5 & 275 & 5.2 & 4.5 & $5.7 * \star$ \\
\hline No & 1,917 & 68.2 & 66.4 & 70.0 & 8,558 & 91.0 & 90.4 & 91.6 & 5,024 & 94.8 & 94.0 & 95.4 \\
\hline \multicolumn{13}{|l|}{ CD4 (cells/mm³) } \\
\hline$<350$ & 1,972 & 72.5 & 70.8 & 74.2 & 7,242 & 79.3 & 78.5 & 80.2 & 3,332 & 66.1 & 64.7 & $67.4 * *$ \\
\hline $350-500$ & 380 & 13.9 & 12.6 & 15.3 & 939 & 10.3 & 9.6 & 10.9 & 862 & 17.1 & 16.0 & 18.1 \\
\hline$\geq 500$ & 368 & 13.5 & 12.2 & 14.8 & 942 & 10.3 & 9.7 & 10.9 & 847 & 16.8 & 16.0 & 18.1 \\
\hline \multicolumn{13}{|l|}{ AIDS stage $\star \star \star$} \\
\hline$A$ & 1,217 & 43.9 & 42.0 & 45.7 & 4,223 & 46.6 & 18.9 & 21.9 & 3,414 & 69.3 & 33.8 & $37.3 * *$ \\
\hline $\mathrm{B}$ & 567 & 20.5 & 44.5 & 46.6 & 1,785 & 19.3 & 18.4 & 20.0 & 492 & 10.0 & 34.1 & 36.0 \\
\hline C & 986 & 35.6 & 68.0 & 70.5 & 3,256 & 35.1 & 9.1 & 10.8 & 1,020 & 20.7 & 19.5 & 21.0 \\
\hline \multicolumn{13}{|l|}{ TB-HIV coinfection } \\
\hline Yes & 157 & 10,2 & 9.0 & 11.7 & 466 & 9.5 & 9.0 & 10.3 & 147 & 10.3 & 9.8 & $11.9 * *$ \\
\hline No & 1,389 & 89.8 & 88.2 & 91.3 & 4,451 & 90.5 & 89.6 & 91.3 & 1,287 & 89.7 & 88,1 & 91.2 \\
\hline \multicolumn{13}{|l|}{ Death cause } \\
\hline TB-HIV & 88 & 13.6 & 11.1 & 16.4 & 56 & 12.9 & 10.1 & 16.5 & 13 & 12.1 & 7.2 & $19.8 * \star$ \\
\hline Another condition & 559 & 86.4 & 83.5 & 88.8 & 376 & 87.0 & 83.5 & 89.8 & 134 & 87.5 & 80.2 & 92.8 \\
\hline \multicolumn{13}{|l|}{ Cholesterol HDL } \\
\hline High risk & 509 & 59.7 & 56.4 & 62.9 & 2,449 & 61.3 & 59.7 & 62.7 & 1,376 & 60.7 & 58.7 & $62.7 * \star$ \\
\hline Normal & 344 & 40.3 & 37.0 & 43.6 & 1,548 & 38.7 & 37.2 & 40.2 & 890 & 39.3 & 37.2 & 41.3 \\
\hline \multicolumn{13}{|l|}{ Cholesterol LDL } \\
\hline High risk & 60 & 10.7 & 8.1 & 13.3 & 248 & 11.1 & 9.8 & 12.4 & 215 & 11.3 & 87.2 & 90.0 ** \\
\hline Normal & 497 & 89.2 & 86.6 & 91.8 & 1,980 & 88.8 & 87.5 & 90.1 & 1,683 & 88.7 & 9.9 & 12.7 \\
\hline \multicolumn{13}{|l|}{ Triglycerides } \\
\hline Severe risk & 34 & 2.0 & 1.3 & 2.7 & 82 & 1.5 & 1.1 & 1.7 & 30 & 0.8 & 0.5 & $1.1 * *$ \\
\hline High & 648 & 39.8 & 37.4 & 42.2 & 2,198 & 39.2 & 37.9 & 40.5 & 1,234 & 34.2 & 32.6 & 35.7 \\
\hline Normal & 945 & 58.0 & 55.6 & 60.4 & 3,317 & 59.3 & 57.9 & 60.5 & 2,344 & 65.0 & 63.4 & 66.5 \\
\hline
\end{tabular}

95\% Cl: 95\% confidence interval; TB: tuberculosis.

Source: Chilean AIDS Cohort, 2000-2017.

* The differences in the "total n" are due to "missing values";

** It represents total proportions and significant differences for Fisher's exact and Pearson's chi-square test (significance probability of error < 0.001);

*** A: asymptomatic infection, B: symptomatic infection with non-defining AIDS, and C: AIDS-defining conditions.

(HR $=1.9 ; 95 \%$ CI: 1.2-3.0) had worse outcomes. Patients coinfected with TB-HIV have much shorter survival time when compared with people that entered ART with other pathologies or developed other coinfections, even across the long duration of this dataset. This raises serious questions about the HIV/ AIDS care model in the public health system in Chile (Table 3).

$$
\begin{gathered}
h(t \mid x 1, x 2 \ldots, k 3)=h 0(t) \exp (\beta 1 x 1+\beta 2 x 2+\ldots+\beta k x k) \\
h(t \mid x)=h 0(t) \exp (1.4 T B-H I V+3.3 C D 4+1.9 V L)
\end{gathered}
$$

Equations 4 and 5 describe the hazard - intensity with the deaths to AIDS and TB-HIV coinfection occur in the Chilean AIDS Cohort - as a function of $h(t \mid x)$ for the presence of multiple predictors in which case $\beta x 1$ is a column vector of regression coefficients. Where: $h(t)=$ baseline hazard in time $t ; x k=$ predictive variable; and $\beta k=$ constant associated with the variable $k$. 
Figure 2

Survival curves people living with HIV/AIDS according to sociodemographic predictors of people on highly active antiretroviral therapy Chilean AIDS Cohort, 2000-2017.

2a) Sex

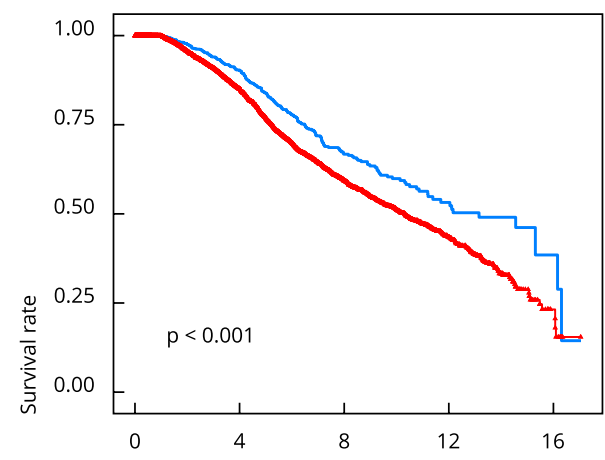

2c) TB-HIV coinfection

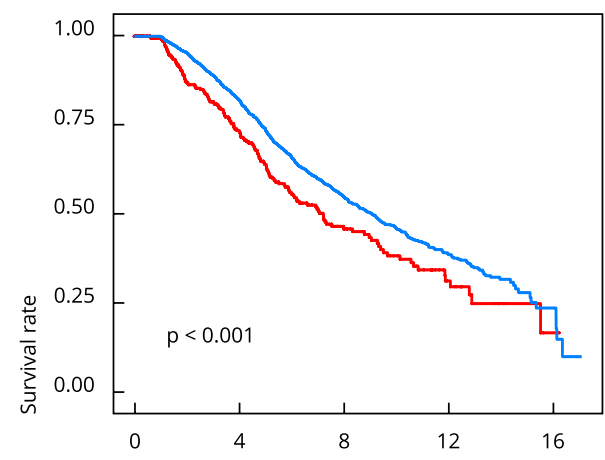

2b) Educational level
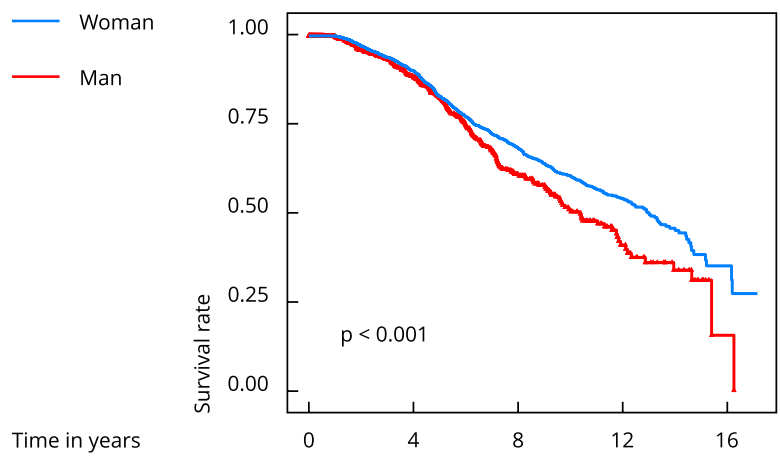

_ High school or University

__ Elementary or less

2d) LT-CD4

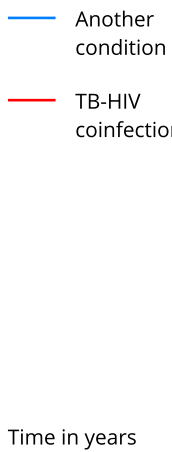

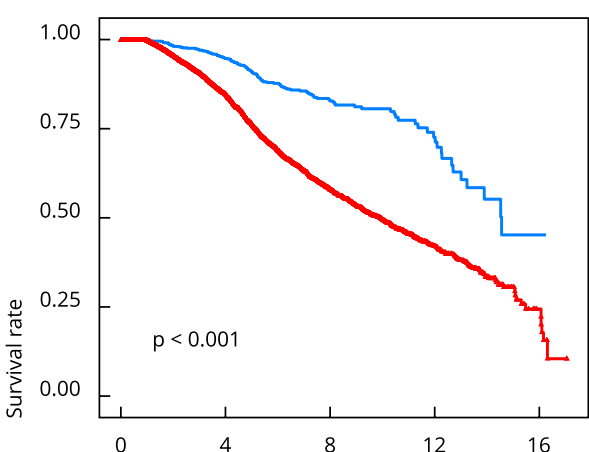

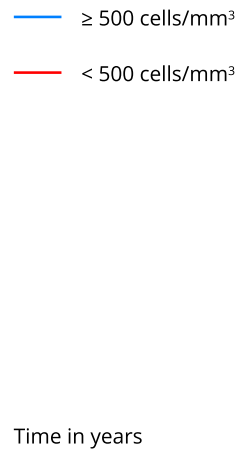

Source: Chilean AIDS Cohort analysis, 2000-2017, and Chilean National Institute of Statistics (INE).

When assessing the risk of death due to coinfection with TB-HIV after the start of ART, we observe a higher chance of death, and a reduction in life expectancy associated with a number of different modifiable factors, implying serious questions about prevention, control and treatment. Since $\mathrm{TB}$ is a treatable disease, this represents a strong indicator of inequality in programming and delivery.

\section{Discussion}

Between 2000 to 2017, 157 deaths due to TB-HIV coinfection were registered, which represents 13.3\% of the total deaths in PLWHA in the Chilean AIDS Cohort. This represents a failure of treatment in a marginalized population with less access to public health, as reported in other studies in the country 31,32. Diagnosis of TB in HIV-positive persons can be limited, in part, to poor infrastructure and failure to address issues of culture, as demonstrated in studies conducted in Latin America countries, added to a delay in the start of ART and multidrug resistant TB 22,33.

After analyzing overall mortality, which includes 17 years of observation of PLWHA in treatment in the public health system, we showed a higher mortality due to the effect of comorbidities, in which 
Table 3

Hazard ratio (HR) of sociodemographic and epidemiological predictors associated with death in populations coinfected by TB-HIV on highly active antiretroviral therapy. Chilean AIDS Cohort, 2000-2017.

\begin{tabular}{|c|c|c|c|c|c|c|}
\hline Variable & HR crude & $95 \% \mathrm{Cl}$ & p-value & HR adjusted * & $95 \% \mathrm{Cl}$ & p-value \\
\hline \multicolumn{7}{|l|}{ Education } \\
\hline High school or Universiry & 1.00 & Reference & 0.23 & 1.00 & Reference & 0.24 \\
\hline Elementary or less & 1.45 & $0.78-2.70$ & & 1.44 & $0.77-2.69$ & \\
\hline \multicolumn{7}{|l|}{ Indigenous population ** } \\
\hline Chilean or migrant & 1.00 & Reference & $<0.01$ & 1.00 & Reference & $<0.01$ \\
\hline Indigenous & 5.16 & 2.03-13.08 & & 5.24 & $2.05-13.9$ & \\
\hline \multicolumn{7}{|l|}{ Key population } \\
\hline Another key population $* \star *$ & 1.00 & Reference & & 1.00 & Reference & \\
\hline MSM & 0.48 & $0.28-0.82$ & 0.001 & 0.34 & $0.19-0.60$ & $<0,01$ \\
\hline \multicolumn{7}{|l|}{ CD4 (cells/mm³) } \\
\hline$<350$ & 1.00 & Reference & & 1.00 & Reference & \\
\hline $351-500$ & 0.27 & $0,10-0,76$ & 0.01 & 0.32 & $0.11-0.89$ & 0.03 \\
\hline$\geq 500$ & 0.06 & $0,08-0,46$ & $<0.01$ & 0.07 & $0.01-0.56$ & 0.01 \\
\hline
\end{tabular}

95\% Cl: 95\% confidence interval; MSM: men who have sex with men.

Source: Chilean AIDS Cohort, 2000-2017.

* Adjusted by age, education and sex;

** Aymara indigenous people represent 32\% and Mapuche indigenous people represent $60.3 \%$ of indigenous population;

$\star \star \star$ Sex workers, injection drug users, population deprived of liberty, and heterosexual population.

the TB-HIV coinfection is the most relevant. Differences by educational level, gender and indigenous ethnicity are also evident. Reports from the Chilean Ministry of Health indicate that the incidence of TB increased, reaching 15.6 cases per 100,000 inhabitants in 201734.

Our most important finding was the confirmation of a scenario of an accelerated feminization of HIV/AIDS in Chile, which means a reduction in the male-female ratio, decreasing from 7.2 in the period 2007-2009 to 5.2 men every woman living with HIV/AIDS in the 2010-2017 period. This decrease has been accelerating in recent decades, which coincides with the findings from other studies $13,35,36$.

Estimates indicate that in the Latin American and Caribbean region there would be 2.1 million and 330,000 PLWHA, respectively, in 2019, and 132,000 new infections in the population over 15 years-old 37 . These numbers reflect the inadequacy of control and prevention programs, since these data show only a slight decrease since the last report in 2016, with 120,000 new HIV infections, far from the path to the $90 \%$ reduction target by 20301,3 .

Regarding key populations, men who have sex with men (MSM) constitute the largest group of new cases (60\%) for the period 2014-2017. These findings are consistent with other studies conducted among MSM, using respondent-driven sampling (RDS) in the Santiago Metropolitan Region 38,39,40, prevalence studies conducted in Latin American countries 41,42,43 and Angola in Sub-Saharan Africa 44.

Selected areas of Chile showed a progressive and chronic increase in the prevalence of HIV/AIDS in the adult population, of 5.3 per 100,000 inhabitants, particularly in the northern regions of the country (Arica y Parinacota, Tarapacá, Antofagasta) and in the center of the country (Valparaíso and the Santiago Metropolitan Region). There are multiple reasons for this uneven pattern of AIDS and TB-HIV mortality. In urban areas, the availability of ART and test-and-treat have led to prevention and avoidance of services that aid transmission. In more rural and marginalized areas, especially indigenous areas, the lack of consistent public HIV programs, history of relatively low prevalence, and poor access to care exacerbate the conditions of marginality.

Studies in Brazil among MSM show that HIV rates are rising steeply among young populations, who report early sexual initiation, a high number of sexual partners and lack of condom use 35,37 . 
Not only for Brazil, but, for example, a study conducted in the province of Luanda (Angola) by our group 44 showed that the opening of borders and the pace of social change such as rapid urbanization, internal and external migration, low levels of HIV knowledge and perceived risk, diversity of sexual encounters and low condom use may contribute to increasing HIV infection among MSM. Given what we know about TB and HIV, and the late initiation of ART, programs addressing TB need to be reinforced.

\section{Conclusion}

Our findings showed that there is a lower probability of survival in TB-HIV coinfected people in the Chilean AIDS Cohort, especially for those with a delay in the initiation of ART. Furthermore, there is a concentration of the epidemic at younger ages. There is a process of accelerated feminization of the epidemic, and spread to vulnerable emerging groups such as the Aymaras indigenous population in northern Chile, indigenous Mapuche in the center and south of the country, and among migrants. We strongly advocate for the need to improve access to community-based TB and HIV testing, targeted sex and health education in schools and structural interventions to reduce stigma and discrimination, both for sexual and ethnic minorities. Social policies to protect the human rights of minorities and vulnerable populations are required. Thinking of the overall investments in health care and ART, the potential for ongoing transmission, and the emergence of MDR-TB, not investing in improved TB programs seems counterintuitive.

\section{Study limitations}

Due to limitations of our data, we could not explore more robustly coinfection with TB-HIV in indigenous groups. However, our results do suggest the direction of the rapidly evolving phenomenon of HIV/AIDS and coinfections of the TB-HIV epidemic in Chile.

\section{Contributors}

C. Sanhueza-Sanzana contributed to the study conception, data collection, analysis and interpretation, and manuscript writing. L. Kerr contributed to the study conception and design, methodology, software ownership, analysis and interpretation, and review and editing. $\mathrm{C}$. Kendall contributed to the study conception and review and editing. All authors approved the final version of the manuscript.

\section{Additional informations}

ORCID: Carlos Sanhueza-Sanzana (0000-00026021-564X); Ligia Kerr (0000-0003-4941-408X); Carl Kendall (0000-0002-0794-4333).

\section{Conflict of interest}

The authors declare that they have no potential conflicts of interest regarding the research, authorship and/or publication of this article.

\section{Acknowledgments}

C. Sanhueza-Sanzana thanks the Brazilian National Research Council (CNPq; n. 133129/2018-7) in partnership with the Organization of American States. We also thank the Chilean Ministry of Health for providing the data used throughout the present study. 


\section{References}

1. Joint United Nations Programme on HIV/ AIDS. Miles to go: closing gaps breaking barriers righting injustices. https://www.unaids. org/sites/default/files/media_asset/miles-togo_en.pdf (accessed on 03/Jul/2020).

2. Joint United Nations Programme on HIV/ AIDS. Ending AIDS: progress towards the 9090-90 targets. https://www.unaids.org/en/re sources/documents/2017/20170720_Global_ AIDS_update_2017 (accessed on 03/Jul/2020).

3. Organización Panamericana de la Salud; Programa Conjunto de las Naciones Unidas sobre el VIH/Sida para América Latina y el Caribe. Prevención de la infección por el VIH bajo la lupa. Un análisis desde la perspectiva del sector de la salud en América Latina y el Caribe. https://www.paho.org/prevencion-vih-lalupa-2017/ (accessed on 03/Jul/2020).

4. Programa Conjunto de las Naciones Unidas sobre el VIH/Sida. Un largo camino por recorrer: la respuesta al VIH en América Latina. https://www.unaids.org/sites/default/ files/media_asset/miles-to-go_latin-america_ es.pdf (accessed on 03/Jul/2020).

5. Cáceres K, Pino R. Estimaciones poblacionales sobre VIH en Chile 2017 SPECTRUM, ONUSIDA. Rev Chil Infectol 2018; 35:642-8.

6. Cáceres K. Informe: situación epidemiológica de las infecciones de transmisión sexual en Chile, 2017. Rev Chil Infectol 2019; 36:221-33.

7. Ministerio de Salud. Informe nacional: evolución de la infección por VIH/SIDA Chile 1984-2012. Rev Chil Infectol 2015; 32:17-43.

8. Pan American Health Organization. Tuberculosis in the Americas 2018. https://iris.paho. org/handle/10665.2/49510 (accessed on 25/ Apr/2019).

9. World Health Organization. Global tuberculosis report 2018. https://www.who.int/tb/pu blications/global_report/en/ (accessed on 03/ Jul/2020).

10. Trickey A, May M, Vehreschild J, Obel N, Gill MJ. Survival of HIV-positive patients starting antiretroviral therapy between 1996 and 2013: a collaborative analysis of cohort studies. Lancet HIV 2017; 4:349-56.

11. Gamboa B, Zambrano RE, Lizzetti G, Soto A, Lucchetti A. Factores asociados a sobrevida en pacientes con co-infección VIH-TBC en el Servicio de Infectología del Hospital Nacional Arzobispo Loayza, Perú, durante los años 2004-2012. Rev Chil Infectol 2018; 35:41-8.

12. Melo MC, Mesquita FC, Barros MBA, La-Rotta EIG, Donalisio MR. Sobrevida de pacientes com aids e associação com escolaridade e raça/ cor da pele no Sul e Sudeste do Brasil: estudo de coorte, 1998-1999. Epidemiol Serv Saúde 2019; 28:1998-9.
13. Beltrán C, Zitko P, Wolff M, Bernal F, Asenjo A, Fernández AM, et al. Evolución de las características epidemiológicas y clínicas de pacientes adultos del programa nacional al inicio de la terapia anti-retroviral en la Cohorte Chilena de SIDA, 2001-2015. Rev Chil Infectol 2016; 33 Supp 1:2-10.

14. Martin LJ, Houston S, Yasui Y, Wild TC, Saunders LD. All-cause and HIV-related mortality rates among HIV-infected patients after initiating highly active antiretroviral therapy: the impact of aboriginal ethnicity and injection drug use. Can J Public Health 2011; 102:90-6.

15. Graeff S, Pícolli R, Arantes R, De Castro V, da Cunha R. Epidemiological aspects of HIV infection and AIDS among indigenous populations. Rev Saúde Pública 2019; 53:71.

16. Ponce P, Muñoz R, Stival M. Pueblos indígenas, VIH y políticas públicas en Latinoamérica: una exploración en el panorama actual de la prevalencia epidemiológica, la prevención, la atención y el seguimiento oportuno. Salud Colect 2017; 13:537-54.

17. Alarcón AM, Chahin C, Muñoz S, Wolff M, Northland R. Persons living with HIV/AIDS: ethnic and sociocultural differences in Chile. Rev Chil Infectol 2018; 35:276-82.

18. Pedrero MM. Situación de salud de la población Aymara en la Región de Arica y Parinacota. Evidencias de inequidades étnicas en el norte de Chile. http://www.seremisalud15.cl/ docs/saludPoblacionAymara.pdf (accessed on 03/Jul/2020).

19. Wilkinson RG. Socioeconomic determinants of health. Health inequalities: relative or absolute material standards? BMJ 1997; 314:591-5.

20. Sandoval MH, Turra CM. El gradiente educativo en la mortalidad adulta en Chile. Revista Latinoamericana de Población 2015; 9:7-35.

21. Batista J, Albuquerque MFPM, Maruza M, Ximenes RAA, Santos ML, Montarroyos UR, et al. Incidence and risk factors for tuberculosis in people living with HIV: cohort from HIV Referral Health Centers in Recife, Brazil. PLoS One 2013; 8:e63916.

22. Crabtree-Ramírez B, Jenkins C, Jayathilake K, Carriquiry G, Veloso V, Padgett D, et al. HIVrelated tuberculosis: mortality risk in persons without vs. with culture-confirmed disease. Int J Tuberc Lung Dis 2019; 23:306-14.

23. Knapp R, Cortes CP, Saavedra F, Wolff M, Weitzel T. Hepatitis B prevalence and influence on HIV treatment outcome and mortality in the Chilean AIDS Cohort. Int J Infect Dis 2013; 17:e919-24.

24. Ministerio de Salud. Guía clínica AUGE: síndrome de la inmunodeficiencia adquirida VIH/ SIDA. http://www.repositoriodigital.minsal.cl/ bitstream/handle/2015/497/VIH_SIDA-2013. pdf? sequence $=1$ \&isAllowed $=y$ (accessed on $25 /$ Jun/2019). 
25. Instituto Nacional de Estadísticas. Estimaciones y proyecciones de la población de Chile 2002-2035 totales regionales. https://www.ine. $\mathrm{cl} /$ estadisticas/sociales/demografia-y-vitales/ proyecciones-de-poblacion (accessed on 25/ Jun/2019)

26. Instituto Nacional de Estadísticas. Sintesis de resultados: Censo 2017. https://www.censo2017.cl/descargas/home/sintesis-de-resulta dos-censo2017.pdf (accessed on 03/Jul/2020).

27. Cleves M, Goould W, Marchenko Y. An introduction to survival analysis using stata. 3 rd Ed. College Station: Stata Press; 2016.

28. Carvalho MS, Andreozzi VL, Codeço CT, Campos DP, Barbosa MTS, Shimakura SE. Análise de sobrevivência: teoria e aplicações em saúde. 2nd Ed. Rio de Janeiro: Editora Fiocruz; 2019.

29. Rabe-Hesketh S, Skrondal A. Multilevel and longitudinal modeling using stata. 3rd Ed. v. II: categorical responses, counts, and survival. College Station: Stata Press; 2012.

30. Ministerio de Salud. Plan nacional de prevención y control del VIH/SIDA e ITS: 20182019. https://diprece.minsal.cl/wp-content/ uploads/2019/06/2019.06.12_PLAN-NACIO NAL-VIH-SIDA-E-ITS.pdf (accessed on 03/ $\mathrm{Jul} / 2020)$

31. Fica A, Herrera T, Aguilera X. El deterioro de la tuberculosis en Chile. Rev Méd Chile 2019; 147:1042-52.

32. Villarroel L, Rabagliati R, Balcells ME, Karzulovic L, Pérez C. Tuberculosis en individuos con infección por VIH en Chile: estudio de prevalencia e impacto sobre mortalidad. Rev Méd Chile 2008; 136:578-86.

33. Crabtree-Ramírez B, Caro-Vega Y, Shepherd BE, Grinsztejn B, Wolff M, Cortes CP, et al. Time to HAART initiation after diagnosis and treatment of opportunistic infections in patients with AIDS in Latin America. PLoS One 2016; 11:e0153921.

34. Ministerio de Salud. Informe de situación epidemiológica y operacional del Programa Nacional de Tuberculosis 2017. https://diprece.minsal.cl/wp-content/ uploads/2018/10/2018.10.05_TUBERCULO SIS-2017.pdf (accessed on 03/Jul/2020).

35. Rodríguez M, Wolff M, Cortés C. Características clínicas y epidemiológicas de la infección por VIH en inmigrantes latinoamericanos versus chilenos: estudio comparativo en un centro de atención de Santiago a partir de registros de 2003-2013. Rev Chil Infectol 2015; 32 Suppl 1: 72-80.
36. Belmar J, Stuardo V. Adherencia al tratamiento anti-retroviral para el VIH/SIDA en mujeres: una mirada socio-cultural. Rev Chil Infectol 2017; 34:352-8.

37. Joint United Nations Programme on HIV/ AIDS. Global HIV \& AIDS statistics - 2020 fact sheet. https://www.unaids.org/sites/de fault/files/media_asset/UNAIDS_FactSheet_ en.pdf (accessed on 09/Oct/2020).

38. Stuardo V, Fuentes M, Muñoz R, Bustamante L, Faba A, Belmar J, et al. Prevalence and risk factors for HIV infection in a population of homosexual, bisexual, and other men who have sex with men in the Metropolitan Region of Chile: a reemerging health problem. AIDS Behav 2020; 24:827-38.

39. Ministerio de Salud. Estudio de prevalencia de VIH y factores asociados en hombres que tienen sexo con hombres. https://dipre ce.minsal.cl/wrdprss_minsal/wp-content/ uploads/2015/01/Prevalencia-VIH-en-HSHCHIPREV-2010.pdf (accessed on 09/Oct/ 2020).

40. Gómez F, Barrientos J, Cárdenas M. Relation between HIV status, risky sexual behavior, and mental health in an MSM sample from three Chilean cities. Rev Panam Salud Pública 2017; 41:e4.

41. Sabidó M, Kerr LRFS, Mota RS, Benzaken AS, Pinho AA, Guimaraes MDC, et al. Sexual violence against men who have sex with men in Brazil: a respondent-driven sampling survey. AIDS Behav 2015; 19:1630-41.

42. Landmann SC, Souza Júnior PRB, Damacena GN, Barbosa Júnior A, Kendall C. Analysis of data collected by RDS among sex workers in 10 Brazilian cities, 2009: estimation of the prevalence of HIV, variance, and design effect. J Acquir Immune Defic Syndr 2011; 57:12935.

43. Kerr L, Kendall C, Guimarães MDC, Salani MR, Veras MA, Dourado I, et al. HIV prevalence among men who have sex with men in Brazil: results of the 2nd national survey using respondent-driven sampling. Medicine (Baltimore) 2018; 97(1S):S9-15.

44. Kendall C, Kerr LR, Mota RM, Cavalcante S, Macena R, Chen S, et al. Population size, HIV, and behavior among MSM in Luanda, Angola: challenges and findings in the first ever HIV and syphilis biological and behavioral survey. J Acquir Immune Defic Syndr 2014; 66:544-51. 


\section{Resumen}

El objetivo del estudio fue evaluar los factores sociodemográficos y epidemiológicos asociados con la mortalidad por SIDA y por coinfección tuberculosis-VIH en la población chilena adulta entre los años 2000 y 2017. Se trata de un estudio observacional retrospectivo, evaluando la densidad de incidencia de muertes por la coinfección TB-VIH en una población sobre 14 años de edad. Usamos informaciones de la base de datos de la Cohorte Chilena de SIDA, donde 17.512 personas estaban inscritas en terapia antirretroviral altamente activa dentro del sistema público de salud en Chile. Se aplicaron la función de supervivencia de KaplanMeier y la regresión de Cox. Se registró una densidad de incidencia de 0,05 en cada 39,283 personaaños para la mortalidad por coinfección TB-VIH, con un incremento de nuevos casos en personas que viven con SIDA entre las poblaciones indigenas Aymara y Mapuche. Los factores de riesgo incluyeron $C D 4<500$ células $/ \mathrm{mm}^{3}(H R=3,2$; IC95\%: 2,2-4,9), la carga viral al comienzo del tratamiento $>10,000$ copias $/ u L(H R=1,3$; IC95\%: 1,2-1,6), por otro lado, contar con una escolaridad alta $o$ educación superior $(H R=0,76$; IC95\%: 0,6-0,9) es un factor protector para la mortalidad por coinfección TB-VIH. La mortalidad estuvo concentrada en personas coinfectadas por TB-VIH con una mortalidad elevada entre mujeres y poblaciones indígenas. El estudio contribuye al reconocimiento creciente del papel de los determinantes sociales en los desenlaces de la enfermedad, y la necesidad de mejorar el sistema de pruebas, centrado y basado en la comunidad, educación sexual en las escuelas, e intervenciones estructurales para reducir la mortalidad de adultos en la población chilena.

VIH; SIDA; Tuberculosis; Adulto; Mortalidad

\section{Resumo}

O objetivo do estudo foi avaliar os fatores sociodemográficos e epidemiológicos associados à mortalidade por aids e por coinfecção tuberculose-HIV na população adulta chilena entre 2000 e 2017. Este foi um estudo observacional retrospectivo que avaliou a densidade de incidência da mortalidade por coinfecção TB-HIV na população acima de 14 anos de idade. Usamos informações da base de dados da Coorte Chilena de Aids, e 17.512 pessoas estavam inscritas na terapia antirretroviral altivamente ativa através do sistema de saúde pública chileno. Foram aplicadas a função de sobrevida de Kaplan-Meier e a regressão de Cox. Foi observada densidade de incidência de 0,05 para 39.283 pessoas-ano de mortalidade por coinfecção TB-HIV, com um aumento de casos novos em pessoas vivendo com aids entre as populações indígenas Aymara e Mapuche. Os fatores de risco foram CD $4<500$ células $/ \mathrm{mm}^{3}$ (HR = 3,2; IC95\%: 2,2-4,9), carga viral no início do tratamento > 10.000 cópias $/ u L$ (HR = 1,3; IC95\%: 1,2-1,6). O Ensino Médio completo ou mais como escolaridade foi fator de proteção para a mortalidade por coinfecção TB-HIV (HR =0,76; IC95\%: 0,6-0,9). A mortalidade esteve concentrada em pessoas com coinfecção TB-HIV em mulheres e populações indígenas. $O$ artigo contribui para o reconhecimento crescente do papel dos determinantes sociais nos desfechos da doença, chamando atenção para a necessidade de melhorar a testagem centrada e baseada na comunidade, a educação sexual nas escolas e intervenções estruturais para reduzir a mortalidade na população adulta chilena.

HIV; AIDS; Tuberculose; Adulto; Mortalidade
Submitted on $21 / \mathrm{Jul} / 2020$

Final version resubmitted on 14/Oct/2020

Approved on 26/Oct/2020 
Sanhueza-Sanzana C, Kerr L, Kendall C. Mortality from AIDS and tuberculosis-HIV coinfection in the Chilean AIDS Cohort of 2000-2017. Cad Saúde Pública 2021; 37(6):e00212920.

doi: 10.1590/0102-311XER212920

Where it reads:

Rua Prof. Costa Mendes 1608, Fortaleza, CE 60431-970, Brasil.

It should read:

Rua Prof. Costa Mendes 1608, Fortaleza, CE 60430-140, Brasil.

Where it reads:

$R i=\frac{D i}{P i}$ Expressed per 100,00 inhabitants

It should read:

$R i=\frac{D i}{P i}$ Expressed per 100,000 inhabitants

Where it reads:

20. Sandova MH, Turra CM. El gradiente educativo en la mortalidad adulta en Chile. Revista Latinoamericana de Población 2015; 9:7-35.

It should read:

20. Sandoval MH, Turra CM. El gradiente educativo en la mortalidad adulta en Chile. Revista Latinoamericana de Población 2015; 9:7-35. 